\title{
CHANGING EMPLOYMENT PATTERN AND AGRICULTURAL DISTRESS IN RURAL AREAS OF JAMMU AND KASHMIR
}

Waqas Farooq Kuttay*

\begin{abstract}
A study of employment pattern in a society reflects the economic profile of its people. It is an indicator of the economic differentiation of people in an area. In a traditional agrarian society, the population though engaged in agriculture was largely classified as landowners or as landless labour with a small proportion engaged in artisanal activities. Land as an asset provided power and authority in this context. In a capitalist society, the occupational diversification moves from agriculture to industry and finally to the services sector. The development of the industrial sector was historically seen as advancement for the rural population with the predominance of better employment opportunities as industrial workers. In the case of developing countries, there has been growth in services sector rather than employment in industries. This growth in employment in favor of services is skewed as most of the people are employed in the unorganised sector. This paper will study the movement of labour out of agriculture to other sectors of economy in rural areas of Jammu and Kashmir. It will try to analyse the direction and reason for movement of this labour. This will be preceded with a brief theoretical discussion on changes in employment patterns in rural areas.
\end{abstract}

Keywords: Employment Pattern, Occupational Structure, Jammu and Kashmir, Agricultural Distress, Push Theory, Pull Theory.

\footnotetext{
*M. Phil - Development Studies, Centre for Jawaharlal Nehru Studies, Jamia Millia Islamia, New Delhi Currently enrolled in Ph. D at Department of Political Science, Jamia Millia Islamia, New Delhi. Email:waqasfarooq29@gmail.com, Mobile: 8130533728
} 


\section{Introduction}

Many theories of development argue that in order to grow or develop, the structure of an economy should change with the predominance of manufacturing or industrial activity to be supplemented by a service sector. Kuznets $(1955,1971)$ considered massive 'structural' changes in an economy as important for growth. In order to develop, countries need to move from the primary sector to other sectors of the economy, thus there should be a shift from agriculture to manufacturing industries and services (as cited in Afshan, 2012). He further argues that labour force initially moves out of agriculture to secondary sector, whereas, employment in services sector remains constant over long periods (Kuznets, 1972). Feinstein (1999) argues that developing economies will embark on the same path as western developed economies. Thus, when resources shift from primary to secondary and then tertiary sectors, workers follow the same. This implies that a change in occupational structure is dependent upon a structural transformation of economy. Structural shifts in economy are needed for the growth and development of the country.

Arun Kumar et al. (1975), relying heavily on the vast empirical work of Kuznets (1966, 1974), specify that following types of structural change may be expected in an industrialising economy:

(a) The percentage of the population reliant on agriculture should decline over time.
As a result, there will be a surge in nonagricultural employment.

(b) The percentage of the population reliant on industry is expected to increase over this period.

(c) The upsurge in manufacturing employment should absorb a major part of the outgoing agricultural population.

(d) Within manufacturing, there should be a movement of people from household industry to the non-household industry.

(e) Duringtheinitialstages ofindustrialisation in a country, there may be an increase in the percentage of population dependent on services, but this increase should be less than the increase in manufacturing. The rapid increase in services sector may be expected only at a later stage of development.

The developing countries have defied the theories of classical development economists and the population in these countries is moving out of agricultural towards the services sector. There has been a considerable growth of industrial sector in developing societies but industries have reached a saturation point in terms of employment generation, particularly large-scale industries. The informal sector in industries, particularly in services, employs a large amount of workforce in developing countries.

In India, there has not been a massive shift from agriculture to industries as the 
number of persons employed in agriculture in India in 1983 was 66.28 per cent, in manufacturing it was 11.27 per cent and in services sector it was 22.64 per cent. The same figures for 2006-07 were 50.80 per cent, 13.33 per cent and 35.86 per cent respectively (Planning Commission of India, 2008). Thus, the number of workers employed by different sectors has changed drastically and service sector continues to employ most people in India today. In India, the agricultural sector is going through a crisis, it employs the largest number of people but the productivity is low (Mkhize, 2013). In case of India, there has been growing 'tertiarisation' of economy, the labor is moving out of the agriculture, not to industries, but to service sector (Patnaik, 2011; Mazumdar and Sarkar, 2007). The agriculture sector has also witnessed what has been called as 'feminisation' of agriculture which means that more women are employed in agriculture than males (Chand \& Srivastava, 2014; Kulkarni \& Hatekar, 2013).

In developing countries, the debate regarding the shift of the working population from agricultural sector to the service sector is centered around its reasons. There are two theories that explain the moment of people out of agriculture to non-agricultural sector in developing economies i.e., Growth Theory/ Pull Theory and Distress Theory/Push Theory. According to Growth theory (John Mellor, 1976; Lanjouw \& Shariff, 2004; Hazell and Haggblade, 1991; Nachane et al., 1989;Davis and Bezemer, 2004; Reardon et al., 2006) the moment of people out of agriculture to other sectors is primarily due to the growth in agricultural sector. This growth will lead to increase in incomes, which will inevitably lead to the growth in non-agricultural sector. Distress Theory (Vaidyanathan, 1986; Davis \& Bezemer, 2004; Reardon et al, 2006), on the other hand, focuses on the distress and stagnation in agriculture sector. According to this theory, moment of workforce out of agriculture is the result of less productivity and distress in agriculture. As a result, labour is forced out of agriculture to less productive works. There are other theories as well which describe the emergence of non-agricultural sector. The major factors, according to these theories are education ((Eapen, 1994; Basant, 1993; Jayaraj, 1994; and Samal, 1997), infrastructure (Hazell \& Haggblade, 1991; Shukla, 1992; and Hariss, 1991) and urbanisation (Papola, 1992). Every year, large number of rural labour is moving out of agriculture, shifting to other urban areas in search of income-earning opportunities. Therefore, at micro-level, like in India and particularly in States, the study of changes in occupational structure can help us understand the prospects of employment generation capacity of different sectors and consequently in formulation of better policies.

The focus of this study, therefore, is on studying the employment pattern in rural areas of the State of Jammu and Kashmir. The aim is to show whether the growth of non-agricultural sector is a result of Push factors or Pull factors. The State is still largely 
a rural society. Its population is predominantly employed directly or indirectly in agricultural activities. Since most of the rural population is employed in agriculture, it becomes necessary to study the rural areas.

\section{Changes in Occupational Structure in Rural Areas}

\section{What is Rural Non-Agricultural Sector?}

The term non-farm activity (nonagricultural sector) does not constitute a single, easily classifiable activity, rather it is heterogeneous and is characterised by a complex group of activities. Some of the non-farm activities are related to agriculture, while others are not. The non-farm activities can range from employment in industries, construction, and part-time self-employment in home-based industries, trading or other services. Rural areas present a complex picture of occupations. Some people may be involved in cultivation and some other activity at the same time. Some people even migrate to other areas for work when the cultivation period in their own area is over. It becomes very difficult to categorise rural non-farm activities. Besides there are practical limitations before different agencies and departments while collecting data about the occupation of the people (Basant, \& Kumar, 1989). The World Bank (1978) and International Labour Organisation (1983) blame these practical limitations, which hinders the analysis by which a well-established and consistent definitional framework of nonagricultural activities could be measured (as cited in Basant \& Kumar, p.14). World Bank (1978) further says that, "(non-agricultural) activities lay on, or between, the boundaries of the usual rural-urban and agriculture/nonagriculture categories, and any classification or definition of activities inevitably involves a degree of arbitrariness in imposing a single dividing line on... a continuous spectrum of situations" (as cited in Basant, \& Kumar, p.14). Thus, there is no single and clear classification of rural non-agricultural activities, but all the activities outside agriculture can be classified under this category (Basant \& Kumar).

Rural non-agriculture sector is now employing large number of people in developing countries. The figures are 35 per cent in Asia, 40 per cent in Latin America and 45 per cent in Sub-Saharan Africa (Jonasson \& Helfand, 2008). This sector has received considerable attention in recent decades. In order to study rural non-agricultural sector, a clear definition needs to be given. Lanjouw and Lanjouw (1997) define rural non-agricultural activities as those income-generating activities that are not-agricultural, but take place in rural areas (as cited in Davis, \& Bezemer, 2004). For Mukhopadyay et al. (2008), Rural-NonFarm sector comprises of all those economic activities which take place in rural areas and include both non-household and household industries (National Institute of Science Technology and Development Studies, n.d). Since scholars define Rural Non-Agriculture as those activities, which lie outside agriculture, it becomes necessary here to define what 
agricultural activities are. Agricultural activities are classified as:

"[...] all primary production of food, flowers and fibers, thus it includes growing crops, rearing livestock, horticulture, forestry and fisheries. It excludes any food processing, agricultural services and other primary sectors, such as mining or quarrying."(Davis \& Bezemer, 2004).

Anything outside agriculture and pertaining to rural activities is to be identified as Rural Non-Agricultural Activity. Choi (2004) refers Rural Non-Agricultural sector as those income-earning activities in which a person is employed or self-employed in industries, trade or services.

According to Saith (1992), the main principle to identify a Rural Non-Farm activity is to see whether such activity is performed in a rural area or not (as cited in Choi, 2004). In this case, the location of the activity performed becomes an important criterion for identifying it. If an activity falls behind a designated area then it may not be identified as Rural Non-Agricultural activity. The second definition according to Saith is "based on the linkage approach," which means that if any industrial unit or non-farm activity is able to create substantial development links with the rural population (Choi). Saith (1992) argues that certain things must be kept in consideration while defining Rural Non-Farm activities; such as whether to count subsidiary activities like fishing, aqua-culture, animal husbandry as Non-Farm activities? He argues that Non-Farm activity becomes important only because of limitations in agricultural land and its productivity, therefore those activities which remain immune to the above limitations (specifically pertaining to agricultural land) should be counted as non-farm activities (Choi). He further says that industries in rural areas are part of Non-Agricultural sector.

Mukhopadhyay (1985) divides Rural NonAgriculture activity into two broad models. The first model comprises of activities exhibiting the following traits: initiatives whose primary motive, more or less, is growth and generation of surplus. In this model, labour is hired and certain amount of technology is used. The second model comprises of activities that are seasonal and depend on family labour (most of the time unpaid), technology used is primitive and it caters to the needs of local market. She holds that the pattern of land ownership determines the structure of Rural Non-Agricultural activity in rural areas. If there is more landlessness, the prevalence of first model is more common, and where the is landlessness is minimal, the prevalence of second model is more common.

\section{Relevance of Non-agricultural Sector}

In recent decades, the number of persons employed in the rural rural non-agricultural sector has increased manifold, particularly, in developing countries. Non-agriculture sources provide a major share of income in rural households. In Asia, it is 35 per cent, while in 
Latin America, it is 40 per cent. In Sub-Saharan Africa, it nearly accounts to half of the income (Jonasson \& Helfand, 2008). Further, rural nonagricultural sector has also the capacity to absorb underemployed workforce and prevent rural-urban migration, increase rural income and ultimately contribute to the national growth (Jonasson \& Helfand); de Janvry and Sadoulet (1993); Echeverría (2000); Quijandría et al., (2001); World Bank $(2003,2008)$ argue that rural non-agricultural sector can also be the possible route for rural landless and poor out of poverty (as cited in Jonasson \& Helfand, 2008). It can engage rural surplus labour, spread risks arising out of agricultural uncertainties, boost income of rural farm-based households and better use of comparative advantages which particular areas are endowed with (Davis and Bezemer, 2004).

Similarly, A.K. Mukhopadhyay et al., (2008) summarise that the employment growth in rural areas, particularly in farm sector has not been at par with employment growth in general. Therefore, a proper plan and strategy to develop rural non-farm sector may not only prevent migration of rural labour to urban areas, but it may also reduce the ruralurban income gaps.

\section{What is Distress and Growth?}

So far, we have discussed many of the factors leading to the growth of rural nonagricultural sector. Prominent among those factors are (1) Agricultural Distress/Push Factor and (2) Agricultural Growth/Pull Factor.
Now the question is what can be called as distress and growth? Jatav \& Sen (2013) have mentioned the following indicators of distress and growth:

\section{Indicators of Economic Distress}

(a) Percentage of Rural Households Having No Land for Cultivation: Landlessness pushes households into low livelihood status and can cause members of households to join lower rungs of non-farm employment.

(b) Population Pressure on Cultivated Land in Rural Areas: The land available per household is expected to have a bearing on the degree of dependence on the non-farm sector.

(c) Rural Dependency Ratio: A high dependency ratio increases the distress level of the household and can push it into the non-farm sector associated with low wage rates.

(d) Rural Usual Unemployment Rates: They can act as important push factors for households to enter easy entry unskilled non-farm options that offer low protection of jobs.

\section{Indicators of Growth-Promoting Factors}

(a) Levels of Urbanisation: Urbanisation could potentially have a positive influence on generating non-farm livelihoods, particularly in the rural peripheral regions through spillover effects. This is expected to happen through processes like sub-contracting in neighboring 
regions, which is a rapidly expanding phenomenon.

(b) Average Size of Rural Land in Cultivation, Orchards and Plantations (in hectares): This indicator is a proxy indicator for the potential for investment in the Rural Non-Farm Sector.

(c) Rural Irrigation Ratio: Percentage of irrigated land to cultivated land is closely related to land productivity, and hence, has been taken as an indicator variable for farm income.

\section{The Status of Women}

Most of the women in rural India work at home. As compared to men, the Work Participation Rates of women is very low. Employment opportunities for women have not grown. Srivastava \& Srivastava (2010) argue that in the stagnant rural economy, women are not able to get work, which binds them to work only in the auxiliary activities. On the other hand, women's principal responsibilities lie within the house, but for economic reasons, she has to work. Therefore, those women, who somehow are able to work, have to bear all the household burdens also.

They further say that the reasons for male participation in work primarily influence a woman's participation in work and are diverse and include demographic, reproductive, social, religious and cultural factors.
In rural non-agricultural sector, Srivastava \& Srivastava (2013) argue that the presence of women as regular workers is very low with respect to the total number of regular workers. There is a certain kind of discrimination against the women in rural non-agricultural sector also. They argue that women workers are segmented into certain types to perform activities which determine the gender gap.

\section{Objectives}

1. To analyse the changing employment patterns in rural areas of Jammu and Kashmir

2. To see whether labour is moving out of agriculture or not. If yes, then to which sectors

3. To study whether moment of labor out of agriculture (if it exists) to other sectors is distress-driven or growth-driven

\section{Methodology}

The data sources used for this work are based on various Census conducted by the Government of India and other reports published by the Government of India and the Government of Jammu and Kashmir. The analysis in the study is also based on data from different books, published articles, various online databases like Planning Commission and other government-owned websites. The emphasis of the study is on analysing the changing pattern of employment (the percentages calculated for and after 1981 Census are for'main workers' only) in rural areas 
from 1961 to 2011. The study is quantitative, longitudinal and descriptive in nature.

The sub-sectors which form agriculture/ primary sector in this study include a) cultivators b) agricultural labourers c) plantation, fishing, hunting, etc, and d) mining and quarrying. The sub-sectors within manufacturing/secondary sector are a) manufacturing-Household Industry (HHI), b) manufacturing-Non Household Industry, and c) construction. The services/tertiary sector constitutes all remaining classifications of National Industrial Classification (Census of India, 1961, 1971, 1981, 2001, 2011).

\section{Employment Pattern and Agricultural Distress in Jammu and Kashmir}

Historically, agriculture in Jammu and Kashmir is the mainstay of their economy and reportedly was feudal in character and stagnant. There was presence of a large number of intermediaries providing a link between the State and tenants. The State allowed these intermediaries to collect the revenue on its behalf. The revenue collection system was very cruel, to say the least, with the intermediaries and feudal lords often taking more than what the tenants had to pay, thus forcing them in abject poverty. Other than agriculture, the only option was the household industry. Modern industry was absent. Unlike the British in colonial India, who focused exclusively on industries up to the extent that they build a web of railway network to facilitate their industries, the Dogra rulers did no such thing. Further, the only profitable business in household industry was the shawl industry, but the profits in these industries were also enjoyed by owners, not the workers. The condition of shawl weavers was miserable and they faced more hardships than agricultural tenants and labourers. Further, shawl industry as a lucrative business was urban-oriented. In rural areas, agriculture remained the only source of income and people never tried to change their occupations.

In 1953, land reforms were passed in the State and tenants were made owners of the land. The whole land ownership pattern of the State changed. The cultivators were now owners in their own right. The economy at that time more resembled than the traditional agriculture economy as propounded by development theorists (like Kuznets). As this study focuses on Jammu and Kashmir, it is convenient to say that the case of India replicated itself in Jammu and Kashmir. The industrial base was very weak in the 1950s and most of the people were employed in agriculture. Jammu and Kashmir being a border and disputed State, therefore, proved a risk for investment, which essentially makes it agriculture-dependent.

Further, as Prakash (2000) in his political economy analysis notes that the State is a land-scarce region with only 30 per cent of the total area suitable for cultivation with the cold arid region of Ladakh and hilly areas of Jammu and Kashmir divisions, taking-up most of the land. However, it should be noted that Jammu 
and Kashmir inherited a dismal economy from Dogra rulers and the pre-colonial rulers. Since then, it has not been able to recover.

\section{Changes in Employment Pattern in Rural Areas of Jammu and Kashmir}

As two-thirds of population in the State of Jammu and Kashmir live in rural areas and derives livelihood directly or indirectly from various agriculture-based activities, the analysis in this section deals with the aspects of employment in rural areas in Jammu and Kashmir. An analysis of growth pattern of rural areas of the State indicates a weak manufacturing sector here. As Afshan (2012, p.33) notes that it will continue to remain so, "since the State has no known rich mineral resources which usually provide the base for heavy industries [and also] because of the small population of the State." The evidence indicates that service sector has become a fast-growing sector that attracts labour for employment. The section gives a detailed analysis of the profile of rural economy of the State and the changing employment pattern over decades.
The percentage of males employed in agricultural sector in 1961 was 87.03 per cent and went down to 44.51 per cent in 2011. The same figures for females were 86.69 per cent and 49.88 per cent, respectively.

Manufacturing has almost remained constant from 1961 to 2011 for males, while as for females, it has almost been similar till 2001 and has decreased in 2011. The percentage presence of females in this sector is high because of employment in household industry, rather than non-household industry. The percentage of males employed in manufacturing in 1961 was 4.63 per cent which went up to 11.95 per cent in 2011. There was a slight decline in the percentage of females till 2001 , but a steep decline to 6.78 per cent in 2011.

The service sector witnessed growth both for males and females. The males increased from 8.32 per cent in 1961 to 43.52 per cent in 2011, while as, the same figures for females were 0.71 per cent to 42.42 per cent for the same years, respectively.

Table 1.1: Change in Occupational Structure (NIC) in Rural Areas of Jammu and Kashmir

\begin{tabular}{|l|c|c|c|c|c|c|c|c|}
\hline & \multicolumn{2}{|c|}{1961} & \multicolumn{2}{c|}{1981} & \multicolumn{2}{c|}{2001} & \multicolumn{2}{c|}{2011} \\
\hline & Males & Females & Males & Females & Males & Females & Males & Females \\
\hline Agriculture & 87.03 & 86.69 & 76.05 & 80.82 & 57.70 & 69.86 & 44.51 & 49.88 \\
\hline Manufacturing & 4.63 & 12.58 & 9.82 & 13.41 & 10.84 & 12.46 & 11.95 & 7.69 \\
\hline Services & 8.32 & 0.71 & 14.11 & 5.75 & 31.45 & 17.66 & 43.52 & 42.42 \\
\hline
\end{tabular}

Source: General Economic Tables, Census 1961, 1981, 2001, and 2011, Government of India. 


\section{Change in Employment Pattern in Rural Areas of Jammu and Kashmir-District-wise}

\section{Primary Sector}

Both male and female workers have decreased in the agriculture sector. Overall, male population has decreased drastically from 1961 to 2011. Agriculture has shown decline in almost all districts of the State of Jammu and Kashmir, however, in most of the districts of Kashmir division, the decrease in female percentage in agriculture is more than that of males. In most of the districts in Jammu division and districts of Leh and Kargil, the percentage of women employed in agriculture is more than that of males.

\section{Secondary Sector}

In most of the districts, the percentage increase of males, from 1961 to 2011, in manufacturing sector, is more than that of females. But in the district Budgam, the presence of women in manufacturing sector is more than 30 per cent, much larger than males in the district. The females are mostly employed in household industry and have increased over time for most of the districts in the Kashmir division. The females in all of the districts of Jammu division have left the household industry. The percentage increase in non-household industry has been more for males as compared to females. The growth in manufacturing sector is mostly because of growth in 'construction' and mostly males work in the 'construction' sector.

The household industry majorly consists of the handicraft industry. The handicraft industry forms one of the important sectors for the Jammu and Kashmir economy. It is principally a cottage-based industry and is successful in providing employment to a large chunk of labour force and is the prospective sector for more employment generation in future. Since it is a cottage industry; the need for large amounts of capital investment and substantial infrastructure such as power, buildings and machinery is evidennnt. The three regions of the State - Jammu, Kashmir and Ladakh have different types of crafts and these are (Planning Commission of India, 2003):

1. Kashmir: Kashmiri shawls, carpets,wood carving, namda, chain stitch, papiermache, crewel.

2. Ladakh: Wood carving and painting, clay moulding, thanka and fresha painting, Ladakh carpet.

3. Jammu: Calico painting, phoolkari, Basholi painting.

The non-household industry comprises of silk, woolen, leather, rafal yarn, joinery mills, sports goods, plywood, rosin and turpentine, cement, gypsum and lime, brick plants, dying and combing plants, water plants, juice plants, diary and milk products industries and more. 
Table 1.2: Percentage of Workers in Agriculture (NIC) in Rural Areas of Jammu and Kashmir- District-wise

\begin{tabular}{|c|c|c|c|c|c|c|c|c|c|c|}
\hline \multirow{2}{*}{ Districts } & \multicolumn{2}{|c|}{1961} & \multicolumn{2}{|c|}{1971} & \multicolumn{2}{|c|}{1981} & \multicolumn{2}{|c|}{2001} & \multicolumn{2}{|c|}{2011} \\
\hline & M. & Fem. & M. & Fem. & M. & Fem. & M. & Fem. & M. & Fem. \\
\hline Anantnag & 89.29 & 83.6 & 81.79 & 79.54 & 75.98 & 85.60 & 64.60 & 57.24 & 49.46 & 47.4 \\
\hline Kulgam^^ & - & - & - & - & - & - & - & - & 55.06 & 49.14 \\
\hline Pulwama & - & - & - & - & 74.94 & 68.01 & 62.31 & 58.89 & 36.59 & 29.73 \\
\hline Shupiyan^ & - & - & - & - & - & - & - & - & 71.56 & 58.44 \\
\hline Srinagar & 83.6 & 93.2 & 79.63 & 84.58 & 70.96 & 68.35 & 44.01 & 39.62 & 23.96 & 29.03 \\
\hline Ganderbal^ & - & - & - & - & - & - & - & - & 29.62 & 39.11 \\
\hline Budgam & - & - & - & - & 67.83 & 42.70 & 52.07 & 38.33 & 46.48 & 27.20 \\
\hline Baramullah & 89.68 & 90.99 & 83.31 & 88.35 & 71.21 & 65.19 & 55.21 & 37.71 & 39.92 & 29.39 \\
\hline Bandipore^ & - & - & - & - & - & - & - & - & 40.34 & 31.98 \\
\hline Kupwara & - & - & - & - & 83.98 & 78.63 & 51.22 & 57.63 & 25.24 & 33.89 \\
\hline Ladakh & 88.16 & 88.73 & 84.27 & 96.05 & - & - & - & - & - & - \\
\hline Kargil & - & - & - & - & 88.16 & 88.73 & 84.27 & 96.05 & 8.46 & 33.09 \\
\hline Leh & - & - & - & - & 71.40 & 92.85 & 44.07 & 73.18 & 25.71 & 57.87 \\
\hline Doda & 91.40 & 84.72 & 90.02 & 96.50 & 87.03 & 96.31 & 66.92 & 92.59 & 43.59 & 49.48 \\
\hline Ramban^^ & - & - & - & - & - & - & - & - & 55.51 & 50.01 \\
\hline Kishtwar^ & - & - & - & - & - & - & - & - & 57.28 & 69.83 \\
\hline Udhampur & 89.00 & 78.38 & 86.04 & 86.08 & 81.04 & 87.43 & 66.40 & 91.62 & 57.11 & 76.43 \\
\hline Reasi^ ${ }^{\wedge}$ & - & - & - & - & - & - & - & - & 68.18 & 76.40 \\
\hline Jammu & 75.72 & 91.64 & 74.74 & 53.82 & 67.86 & 55.48 & 44.26 & 60.16 & 38.38 & 42.09 \\
\hline Samba^ & - & - & - & - & - & - & - & - & 28.92 & 31.01 \\
\hline Kathua & 82.12 & 86.64 & 77.04 & 66.95 & 75.14 & 80.41 & 57.36 & 85.62 & 48.79 & 56.77 \\
\hline Poonch & 91.79 & 85.20 & 90.87 & 75.17 & 82.90 & 77.05 & 72.60 & 76.93 & 39.2 & 42.4 \\
\hline Rajauri & - & - & 89.36 & 83.20 & 85.88 & 83.63 & 65.00 & 76.18 & 49.94 & 63.27 \\
\hline
\end{tabular}

Source: General Economic Tables, Census 1961, 1971, 1981, 2001 and 2011, Government of India. Note: ^ The districts were formed in 2006. 


\section{Tertiary Sector}

The services sector has seen a huge increase in all of the districts of Jammu and Kashmir. It is the only sector that has shown a similar trend in all districts of the State.

The service sector includes diverse number of activities. Some of the important activities are (National Classification of Occupations, Census 2001):

a. 'Legislators and administrative officers' in which a very small section of rural population is employed

b. Professionals and technical assistants like architects, doctors and health workers, teachers in higher education and lower education, business personal, lawyers, dentists, computer and IT professionals and pharmacists. The number of personals in these activities is quite high.

c. A large number of workers are unorganised and are employed in services like conductors, travel attendants and guides, personal and security services, sales persons, barbers and personal care workers, waiters, daily wage labourers, miners and stone cutters, bricklayers, stonemasons, carpenters, floor layers and tile setters, small metal related workers, electricians, potters, butchers, fruit and vegetable sellers, weavers and knitters, tailors, leather workers and shoemakers, sweepers and garbage collectors.

\section{Agricultural Distress in the State of Jammu and Kashmir}

The majority of population in the State resides in rural areas and majority of them are employed in agriculture (Table 1.4). Therefore, it can be assumed that distress in agriculture in the State is to a large extent directly related to the rural populace.

\section{Sectoral Contribution to State Domestic Product}

The contribution of different sectors to the Net State Domestic Product makes it clear that in 1960-61, the contribution of agriculture was large than the other two sectors and most of the population was engaged in agriculture at that time (Table 1.2). The contribution of agricultural sector to Net State Domestic Product in 1960-61 was 67.67 per cent and it went down to 32.57 per cent in 2000-01 (Aziz, 2010; Jammu and Kashmir ENVIS Centre, n.d.). The contribution of agriculture to Net State Domestic Product has reduced drastically, but at the same time, agriculture remains the largest sector of the economy because it still engages the largest percentage of labour force. It clearly denotes that agriculture is going through a crisis in the State.

The contribution of the manufacturing sector to Net State Somestic Product has increased continuously, but it stagnated at nearly 20 per cent for the years 1986-87 and 2000-01. The employment in manufacturing sector has also stagnated (Table 1.3). The 
Table 1.3: Percentage of Workers in Manufacturing (NIC) in Rural Areas of Jammu and Kashmir- District-wise

\begin{tabular}{|c|c|c|c|c|c|c|c|c|c|c|}
\hline \multirow{2}{*}{ Districts } & \multicolumn{2}{|c|}{1961} & \multicolumn{2}{|c|}{1971} & \multicolumn{2}{|c|}{1981} & \multicolumn{2}{|c|}{2001} & \multirow{2}{*}{$\begin{array}{c}2011 \\
\text { M. }\end{array}$} & \multirow[b]{2}{*}{ Fem. } \\
\hline & M. & Fem. & M. & Fem. & M. & Fem. & M. & Fem. & & \\
\hline Anantnag & 4.47 & 15.59 & 5.83 & 16.26 & 10.29 & 9.70 & 9.54 & 19.69 & 11.91 & 5.16 \\
\hline Kulgam^^ & - & - & - & - & - & - & - & - & 12.34 & 6.75 \\
\hline Pulwama & - & - & - & - & 11.94 & 22.11 & 9.31 & 13.85 & 12.83 & 10.77 \\
\hline Shupiyan^ & - & - & - & - & - & - & - & - & 6.44 & 1.5 \\
\hline Srinagar & 6.05 & 5.65 & 7.51 & 9.42 & 15.66 & 26.83 & 24.70 & 32.41 & 32.62 & 23.11 \\
\hline Ganderbal^ & - & - & - & - & - & - & - & - & 16.32 & 16.56 \\
\hline Budgam & - & - & - & - & 20.96 & 53.70 & 21.85 & 42.49 & 22.16 & 36.19 \\
\hline Baramulla & 2.71 & 8.46 & 5.09 & 6.96 & 13.87 & 30.32 & 16.28 & 31.90 & 12.77 & 12.43 \\
\hline Bandipore^ & - & - & - & - & - & - & - & - & 18.61 & 28.8 \\
\hline Kupwara & - & - & - & - & 5.12 & 14.51 & 5.99 & 12.43 & 6.92 & 1.88 \\
\hline Ladakh & 5.87 & 10.93 & 2.65 & 2.67 & - & - & - & - & - & - \\
\hline Kargil & - & - & - & - & 3.98 & 0.30 & 12.41 & 1.27 & 5.47 & 1.7 \\
\hline Leh & - & - & - & - & 3.02 & 2.51 & 7.96 & 5.28 & 3.1 & 2.75 \\
\hline Doda & 4.79 & 15.08 & 2.48 & 2.59 & 4.55 & 1.67 & 7.07 & 1.99 & 13.88 & 2.14 \\
\hline Ramban^^ & - & - & - & - & - & - & - & - & 11.3 & 3.28 \\
\hline Kishtwar^ & - & - & - & - & - & - & - & - & 5.55 & 0.72 \\
\hline Udhampur & 4.80 & 21.31 & 4.56 & 10.09 & 7.44 & 6.57 & 4.91 & 1.12 & 11.1 & 2.18 \\
\hline Reasi^ $^{\wedge}$ & - & - & - & - & - & - & - & - & 5.0 & 2.63 \\
\hline Jammu & 5.27 & 5.04 & 8.28 & 27.58 & 9.76 & 21.00 & 12.15 & 10.21 & 14.73 & 7.35 \\
\hline Sambha^ & - & - & - & - & - & - & - & - & 20.0 & 11.33 \\
\hline Kathua & 6.68 & 11.56 & 9.64 & 21.29 & 9.90 & 8.85 & 10.76 & 3.42 & 11.65 & 3.49 \\
\hline Poonch & 4.15 & 14.55 & 2.45 & 10.21 & 3.64 & 10.02 & 6.90 & 8.70 & 4.23 & 2.51 \\
\hline Rajauri & - & - & 3.13 & 6.52 & 3.23 & 5.75 & 5.36 & 3.57 & 6.85 & 3.0 \\
\hline
\end{tabular}

Source: General Economic Tables, Census 1961, 1971, 1981, 2001 and 2011, Government of India. Note: ^ The districts were formed in 2006. 
contribution of manufacturing sector was 8.27 per cent in 1960-61 and it went up to 20.30 per cent in the year 2000-01 (Aziz; Jammu and Kashmir ENVIS Centre).

The services sector contribution to Net State Domestic Product in 1960-61 was 23.61 per cent in 1960-61 and it increased to 47.20 per cent in 2000-01 (Aziz; Jammu and Kashmir ENVIS Centre). The contribution of this sector to Net State Domestic Product is more than the percentage of labour force it employs. Service sector has witnessed a large growth (in terms of employment) as compared to other two sectors (Table 1.4)

"The sectoral contribution of the GSDP (Gross State Domestic Product) at constant prices as per advance estimates for 2013-14 in percentage terms has been 21.07 per cent, 22.39 per cent, and 56.54 per cent of primary, secondary and tertiary sectors" (J\&K in Indian Economy 2014-15, Directorate of Economics and Statistics, Government of Jammu and Kashmir, n.d., p6).

\section{Production of Major Crops and Net Sown Area}

The major crops of the State are rice, maize and wheat and they occupy a major portion of the net sown area in the State. The production of these crops is low when compared to national levels. Low production, meager contribution to State Domestic Product and highest employment makes the agricultural crisis evident in the State. Therefore, labour has no option but to move out of agriculture to other two sectors of economy.

The average yield of rice for 1964-65 in Jammu and Kashmir was 1,897 Kilogram per Hectare $(\mathrm{Kg} / \mathrm{Ha})$ and the same for India was $1,078 \mathrm{Kg} / \mathrm{Ha}$. In 2012-2013, the average yield of rice in Jammu and Kashmir was 2,095 Kg/Ha and the same for India was $2,462 \mathrm{Kg} / \mathrm{Ha}$. Now, the average Indian rice production is slightly higher than that of Jammu and Kashmir, but the rate of increase has been higher for India. Same has been the case with maize production. Initially, the production in Jammu and Kashmir was higher than that of India, but it has declined lately. The average yield of maize in Jammu and Kashmir in 1964-65 was $1,511 \mathrm{Kg} / \mathrm{Ha}$ and the same for India was 1,010 $\mathrm{Kg} / \mathrm{Ha}$ and in 2012-13, average yield in Jammu and Kashmir was $1,648 \mathrm{Kg} / \mathrm{Ha}$ and for India it was $2,552 \mathrm{Kg} / \mathrm{Ha}$. The production of wheat has increased tremendously from 1964-65 to 2012-13 in India, it was $913 \mathrm{Kg} / \mathrm{Ha}$ in 1964-65 which increased to $3,118 \mathrm{Kg} / \mathrm{Ha}$. The same has not been the case with the State of Jammu and Kashmir. The average yield of wheat in Jammu and Kashmir in 1964-65 was $645 \mathrm{Kg} / \mathrm{Ha}$ which went up to $1,596 \mathrm{Kg} / \mathrm{Ha}$ in 2012-13 (Jammu and Kashmir ENVIS Centre, n.d.; J\&K in Indian Economy 2014-15, Directorate of Economics and Statistics, Government of Jammu and Kashmir, n.d., p8).

Rice, maize and wheat occupy the major proportion of net sown area in the State. The above three crops where cultivated on 
Table 1.4: Percentage of Workers in Services (NIC) in Rural Areas of Jammu and Kashmir- Districtwise

\begin{tabular}{|c|c|c|c|c|c|c|c|c|c|c|}
\hline \multirow{2}{*}{ Districts } & \multicolumn{2}{|c|}{1961} & \multicolumn{2}{|c|}{1971} & \multicolumn{2}{|c|}{1981} & \multicolumn{2}{|c|}{2001} & \multicolumn{2}{|c|}{2011} \\
\hline & M. & Fem. & M. & Fem. & M. & Fem. & M. & Fem. & M. & Fem. \\
\hline Anantnag & 6.19 & 0.70 & 12.33 & 4.16 & 13.68 & 4.67 & 25.72 & 23.00 & 38.62 & 47.42 \\
\hline Kulgam^^ & - & - & - & - & - & - & - & - & 32.59 & 44.09 \\
\hline Pulwama & - & - & - & - & 13.08 & 9.85 & 28.30 & 27.10 & 50.57 & 59.49 \\
\hline Shupiyan^ & - & - & - & - & - & - & - & - & 21.98 & 40.01 \\
\hline Srinagar & 10.29 & 1.07 & 12.79 & 5.96 & 13.34 & 4.78 & 31.23 & 27.85 & 43.4 & 47.85 \\
\hline Ganderbal^ & - & - & - & - & - & - & - & - & 54.01 & 44.23 \\
\hline Budgam & - & - & - & - & 11.16 & 3.57 & 26.01 & 19.20 & 31.34 & 36.59 \\
\hline Baramulla & 7.58 & 0.52 & 11.54 & 4.65 & 14.86 & 4.45 & 28.46 & 30.32 & 47.3 & 58.17 \\
\hline Bandipore^ & - & - & - & - & - & - & - & - & 41.04 & 39.81 \\
\hline Kupwara & - & - & - & - & 10.89 & 6.82 & 42.74 & 29.89 & 67.83 & 64.21 \\
\hline Ladakh & 5.95 & 0.31 & 13.04 & 1.26 & - & - & - & - & - & - \\
\hline Kargil & - & - & - & - & 24.04 & 1.33 & 58.88 & 20.56 & 86.05 & 65.2 \\
\hline Leh & - & - & - & - & 25.52 & 4.60 & 47.90 & 21.49 & 71.18 & 39.37 \\
\hline Doda & 3.73 & 0.15 & 7.35 & 0.85 & 8.34 & 1.96 & 25.94 & 5.36 & 42.6 & 48.36 \\
\hline Ramban^^ & - & - & - & - & - & - & - & - & 32.26 & 46.69 \\
\hline Kishtwar^ & - & - & - & - & - & - & - & - & 37.16 & 29.43 \\
\hline Udhampur & 6.15 & 0.26 & 9.33 & 3.78 & 11.48 & 5.97 & 28.62 & 7.21 & 31.77 & 21.37 \\
\hline Reasi^ $\wedge$ & - & - & - & - & - & - & - & - & 26.81 & 20.95 \\
\hline Jammu & 18.96 & 3.27 & 16.94 & 18.63 & 22.33 & 23.47 & 43.41 & 29.58 & 46.88 & 50.55 \\
\hline Sambha^ & - & - & - & - & - & - & - & - & 51.1 & 57.49 \\
\hline Kathua & 11.17 & 1.77 & 13.25 & 11.71 & 14.91 & 10.68 & 31.82 & 10.91 & 39.54 & 39.73 \\
\hline Poonch & 4.00 & 0.22 & 6.64 & 14.59 & 13.41 & 12.90 & 20.44 & 14.30 & 53.62 & 55.08 \\
\hline Rajauri & - & - & 7.45 & 9.94 & 10.83 & 10.58 & 29.58 & 19.77 & 43.19 & 33.72 \\
\hline
\end{tabular}

Source: General Economic Tables, Census 1961, 1971, 1981, 2001 and 2011 Government of India.

Note: ^ The districts were formed in 2006. 
an estimated 781.96 thousand hectares in 1984-85. Out of this, rice was cultivated on 274.99; wheat on 225.40; and maize on 281.57 thousand hectares. Fruits and vegetables were cultivated on 54.91 thousand hectares only. The above three crops (rice, wheat and maize) were cultivated on 852.16 thousand hectares of net sown area in 2008-09. Rice was cultivated on 257.63; maize on 315.81; and wheat on 278.72 thousand hectares. The cultivated area for rice has shown a decline, while the other two have shown an increase. The area under fruits and vegetables increased to 87.42 thousand hectares (Planning Commission of India, 2003).

\section{Changes in the Size of Landholdings and Rise in Landless Population}

The average landholdings size in the State has been decreasing. There has been a large increase in marginal landholdings. There are more households now which own marginal landholdings. Semi-medium and medium landholdings had been on decline. The increase in marginal landholdings means less production and more pressure on land in terms of employment. The percentage of households owning marginal landholdings (less than 0.002 hectare) in 1971-72 was 51.08 per cent, it increased to 70.33 per cent in 200203. The percentage of households owning small landholdings (1.01 to 2 hectares), semimedium landholdings (2.01 to 4 hectares) and medium landholdings (4.01 to 10 hectares) declined. The households owning small landholdings decreased from 28.71 per cent to 14.76 per cent from $1971-72$ to $2002-$ 03 (Sharma, 2010). The percentage of large landholdings (more than 10 hectares) has been very low in the State. Sharma, R. (2010) argues that marginal and small landholdings are not suitable for cultivation because holders of these lands have limited availability of capital for investment. Large number of households possessed marginal and small landholdings in 2002-03, and at the same time, large portion of population was employed in agriculture in State (Table 1.2), it can be said that majority of labour force is forced to work on agriculture or leave agriculture because of distress.

\section{Agricultural Indebtedness and Income}

Indebtedness among farmers is one of the important factors to examine the increasing agricultural distress in an economy. Jammu and Kashmir is one of the States in India which falls under the category of 'neither highest nor lowest' indebted States amongst the farmers. It is among those States which lie in the middle or moderate category (Sajjad, \& Chauhan, 2012). Haroon and Sajjad (2012) argue that pattern of indebtedness in India shows that as much as 61 per cent of farmers/ households which have marginal landholdings are indebted and only 1.2 per cent farmers/ households having semi-medium, medium and large landholdings have any kind of debt. They say "almost 80 per cent of the farmers who are indebted are the marginal and small farmers." 
The percentage of households who have any kind of debt, and are categorised as marginal landholders, was 72.90 per cent in 2003. The percentage of households, who are indebted and owners of small landholdings, was 13.60 per cent for the same year. The same figures for households with semi-medium landholdings and large landholdings were 12.60 per cent and 0.90 per cent for the same year. The households owning large landholdings had very small debts as compared to households from other categories (Sharma, 2007). Therefore, it becomes clear that with the increase in the size of landholding, the chances of having any kind of debt decreases which reinforces the argument, that was made earlier in this section, that size of landholdings is one of the factor which determines the indebtedness among farmer households. The percentage of households having marginal landholdings had increased tremendously in the State of Jammu and Kashmir from 1971-72 to 2002-03.

The sources of income for farmer households also vary according to size of landholdings. Sharma, R. (2007) argues that the size of landholding is an important indicator of the cultivation as a main source of income. $\mathrm{He}$ says that "the importance of cultivation as a main source of income tends to increase with increase in size of holding."The main source of income for households possessing marginal landholdings in the State of Jammu and Kashmir is wage employment than other sources of income. There were zero households (per thousand households) in rural areas of Jammu and Kashmir in 2003, whose primary or main source of income was cultivation, while 26 households depended on wage/salaried employment. The same figure for households with small holdings was 248, and for semimedium it was 601 , for same time period. The number of households that depended on wage/salaried employment among the small and semi-medium landowners was 961 and 13, respectively (Sharma, R. 2007). Hence, it is evident that as one moves up the ladder (size of landholding), cultivation becomes an important source of income. Sharma R. (2007) argues that the possible reason for this could be the fact that cultivation is a less rewarding activity because of higher investment and transaction costs, particularly for those households which own very small or marginal landholdings. Then there is no option for these people than to move out of agriculture and opt for other sources of income. "On the contrary, large holdings size takes care of scaleeconomies, which in turn leads to earning higher income from cultivation" (Sharma, R, 2007).

\section{Unemployment Situation in Rural Areas}

The unemployment rates (usual principal status) in rural areas of the State of Jammu and Kashmir are more than that of the national average. The unemployment rate for males has increased from 2.30 per cent in 1999-00 to 3.10 per cent in 2009-10. The same figure for females is 4.40 per cent and 19.30 per cent 
respectively. The male unemployment rate in rural India was 2.10 per cent for $1999-00$ and 1.90 per cent for 2009-10. The same figure for females is 1.50 per cent and 2.40 per cent respectively (Nengroo, A, 2015).

The rising unemployment rates mean that more people are coming out of agriculture (since agriculture is the major sector in terms of employment) and looking for employment in other two sectors of the economy (Nengroo).

\section{Results}

The analyses done of the data explains the variations in the pattern of the employment structure in rural areas of the State of Jammu and Kashmir.

1. The main sector of the economy, which still employs the largest numbers of workforce, continues to be agriculture. In other words, there has been a slow change in the occupational structure in State of Jammu and Kashmir, but lately services sector is emerging as the major sector of economy.

2. Agriculture has shown decline in almost all the districts of the State of Jammu and Kashmir, however, in most of the districts of Kashmir division, the decrease in female percentage in agriculture is more than that of males.

3. There has been a growth of employment in manufacturing but the percentage increase in non-household industry and construction is more for males as compared to females. The females are mostly employed in household industry and have increased over time for most of the districts of Kashmir division. The females in all of the districts of Jammu division have left the household industry. In the Kashmir division, only in the districts of Leh and Kargil, there has been decline in the percentage of females in $\mathrm{HHI}$.

4. The data also show that the household industry and construction dominate the 'Manufacturing Sector' in terms of employment. There is an absence of large scale industrialisation, the significance of household industry in providing employment is high, but its scope has remained limited over the decades.

5. The data also shows that in comparison to males, females are more employed in household industry and less in 'nonhousehold industry'.

6. There has been a dramatic increase in the services sector which provides employment to males largely.

7. The contribution of agricultural sector to the State Domestic Product has decreased over time. The contribution of the manufacturing sector increased first and then almost stagnated. There has been a huge surge in contribution of services sector.

8. The major crops of the State are rice, maize and wheat, and they occupy the 
major portion of net sown area in the State. The production of all three crops was lower than that of the all India average in 2012-13.

9. The size of operational landholdings has decreased in the State. There has been a huge surge in the size of marginal and small landholdings in the State. The number of landless households has also increased.

10. The percentage of households/farmers having any kind of debt is large for marginal landholdings and very low for households possessing large landholdings.

11. Unemployment has increased continuously for both males and females. The unemployment rate for females is considerably higher. The unemployment rate for rural areas in Kashmir is higher than that of rural India.

As already noted, the State of Jammu and Kashmir has witnessed structural changes in its economy throughout the years post-independence. Agriculture is the most important sector of the economy and continues to employ the largest number of people. Nevertheless, people have moved out of agriculture to other sectors albeit at a very slow pace. As livelihood dependent on agriculture is unsustainable, the diversification of livelihoods, therefore, becomes one important reason for change in occupation among the people.

\section{Conclusion}

It has been argued by many economists, as discussed above, that the level of development of any society is indicated by various factors like Gross Domestic Product, per capita income, Gross National Product, change in occupational structure, and other related factors. When economies have to foray on a developmental path, they cannot afford to focus only on one indicator neither can they afford to ignore the other factors. Development, thus, should be inclusive and multi-dimensional. Further, the factors which affect the development process differ through time and place. Classical development theorists and economists considered change in occupational structure as one of the major factors of development, but sticking to only this aspect will be a gross error. After Second World War, as the decolonisation process started, many new nations were formed. It was argued that these nations will embark upon the same trajectory of development which was used by developed economies of the world. However, these developing countries which had been colonised for a long time witnessed different conditions and situations as they started developing their economies. Thus, the context provided for development of modern industries in developed countries was not same in newly independent States.

As mentioned earlier, after independence, India embarked upon the path of heavy industrialisation at the expense of 
agriculture. At that time, dominant thinking in India supported heavy industries. India also supported the policy of import substitution. The emphasis was laid on capital-intensive industries rather than labor-intensive industries which was quite in contrast to the policies adopted by East Asian countries after 1960's and 70's. The combined result of these policies and many other factors was that the employment generation in manufacturing came to a standstill in India. The only sector which provided employment opportunities to the ever-increasing workforce was services sector. In rural areas, the labour force was moving out of agriculture towards nonagricultural activities. The non-agricultural activities consisted of both manufacturing and services sector, but looking at the data it can be easily concluded that non-agricultural sector is dominated by services sector.

The State of Jammu and Kashmir also witnessed changes in employment pattern from 1950. From the data presented in the thesis, it can be concluded that agriculture still dominates the economy in terms of employment.

The whole picture of the State depicts that the people are moving out of agriculture to services sector. The manufacturing sector has witnessed a saturation point and the number of people employed in secondary sector is a meager percentage of the population. This trend clearly goes against the classical theories discussed earlier in this study. In short, these theories assumed that the development meant moment of labour force out of agriculture to manufacturing first and when a major portion of the labour force is employed in manufacturing only then shift to services is desirable. Since manufacturing sector is unable to accommodate more labour force, the only choice left with the labour, moving out of agriculture, is to opt for services sector.

Generally speaking, there are two theories that explain the moment of labour out of agriculture to the other two sectors of the economy, first, Growth/Pull Theory, and second, Distress/Push theory. The exponents of the Growth Theory argue that the moment of labour out of agriculture is the result of growth in agricultural sector, while as, proponents of Distress Theory advocate that the moment of people out of agriculture is the result of distress in agricultural sector. The focus of this study has been to demonstrate that the change in occupational structure of agricultural population is result of distress rather than growth. The evidence indicates that most of the rural population is driven out in search of employment due to distress in the agricultural sector. There is distress in agriculture in the State of Jammu and Kashmir. Agriculture as a source of livelihood has become unsustainable.

Because of time and resource constraints, this work has looked at only few parameters to study distress in agriculture in Jammu and 
Kashmir. More variables can be studied for Jammu and Kashmir. This study has tried to a deeper understanding of the phenomena. give a detailed account of the changes in There has been little research done on the employment patterns in rural areas in the last changes in employment patterns and possible fifty years so as to open up new areas for future reasons for these changes in rural areas of research in related fields.

\section{Bibliography}

\section{Books}

Aggarwal, A.N., (2006), Indian economy. New Delhi: New Age International Pvt. Ltd.

Chibber, V., (2004), Locked in Place. New Delhi: Tulika Books.

Datta, A., (1973), Perspectives of Economic Development. Madras: Macmillan India.

Kohli, A., (2004), State Directed Development: Political Power and Industrialisation in the Global Periphery. Cambridge: Cambridge University Press, 2004.

Kumar, R., (2011), Research Methodology. New Delhi: Sage Publications.

Kuznets, S., (1972), Modern Economic Growth: Rate, Structure and Spread. New Delhi: Oxford and IBH publishing co.

Mahajan, V.S., (1978), Towards a Theory of Economic Development. New Delhi: S. Chand and Company Ltd.

Mazumdar, D., Sarkar., S, (2008), Globalization, Labor Markets and Inequality in India. New York: Routledge.

Rostow, W.W., (1960), The Stages of Economic Growth:A Non-communist Manifesto. Cambridge: Cambridge University Press.

\section{Chapter in a Book}

Patnaik,U., (2011), Unbalanced Growth, Tertiarization of the Indian Economy and Implications for Mass Living Standards. In P.K. Jha (ed.),Progressive Fiscal Policy in India (pp.299-325). New Delhi:Sage Publications.

\section{Print/E-Journals}

Abraham, V., (2009), "Employment Growth in Rural India: Distress-driven?" Economic and Political Weekly, 44(16), 97-104.

Basant, R., Kumar., B, (1989), "Rural Non-agricultural Activities in India: A Review of Available Evidence." Social Scientist, 17(1), 13-71. 
Basu, D., Kashyap, S., (1992), Rural Non-agricultural mployment in India: Role of Development Process and Rural-urban Employment Linkages. Economic and Political Weekly,27(51), A178-A189.

Binswanger-Mkhize, H., (2013), The Stunted Structural Transformation of the Indian Economy: Agriculture, Manufacturing and the Rural Non-farm Sector. Economic and Political Weekly, 48(26), 5-13.

Chakrabarti, S., Kundu, A., (2009), Rural Non-farm Economy: A Note on the Impact of CropDiversification and Land Conversion in India. Economic and Political Weekly,44(12), 69-75.

Chand R., Srivastava, S., (2014), Changes in the Rural Labour Market and their Implications for Agriculture. Economic and Political Weekly, 49(10), 47-54.

Feinstein, C., (1999), Structural Change in the Developed Countries during the Twentieth Century. Oxford Review of Economic Policy, 15(4), 35-55.

Jatav, M., \& Sen, S., (2013), Drivers of Non-farm Employment in Rural India: Evidence from the 2009-10 NSSO Round. Economic and Political Weekly, 39(40), 14-21.

Kulkarni, S., \& Hatekar, N., (2013), Stereotypical Occupational Segregation and Gender Inequality: An experimental study. Economic and Political Weekly, 48(32), 112-120.

Kumar, A., Vani, B., \& Vyasulu, V., (1995), Structure of Employment as Seen from 1981 and 1991 Censuses: A Preliminary Look, Economic and Political Weekly,30(38), 2375-2388.

Lanjouw, P., \& Shariff, A., (2004), Rural Non-farm Employment in India: Access, Incomes and Poverty Impact. Economic and Political Weekly, 39(40), 4429-4446.

Mazumdar, D., Sarkar,S., (2007), Growth of Employment and Earnings in Tertiary Sector: 1983-2000. Economic and Political Weekly, 42(11), 973-981.

Mickiewicz, T., Zalewska, A., (2006), De-industrialisation: Rowthorn and Wells' Model Revisited. Acta-Oeconomica,56(2), 143-166.

Mukhopadhyay, S., (1985), Rural Non-farm Sector in Asia: A Characterization. Economic and Political Weekly,20(22), 966-968.

Nengroo, A., (2015), Employment and Unemployment Scenario of Jammu and Kashmir. International Journal of Scientific Research in Science and Technology, 01(03), 133-139. Retrieved from http://ijsrst.com/IJSRST151331.php

Patnaik, U., (2008), The Question of Employment and Livelihoods in Labour Surplus Economies. Social Scientist, 36(5), 4-21.

Prakash, S., (2000), Political Economy of Kashmir since 1947. Economic and Political Weekly,35(24), 2051-2060.

Roy, S., (2008), Structural Change in Employment in India since 1980's: How Lewisian Is It? Social Scientist, 36(11), 47-68. 
Sajjad, H., Chauhan C., (2012), Agrarian Distress and Indebtedness in Rural India: Emerging Perspectives and Challenges Ahead. Journal of Geography and Regional Planning, 05(15), 397-408. Retrieved from http://www.academicjournals.org/journal/JGRP/article-full-textpdf/24845F441137

Srivastava, N., Srivastava, R., (2010), Women, Work and Employment Outcomes in Rural India. Economic and Political Weekly, 45(28), 49-63.

Unni, J., (1998), Non-agricultural Employment and Poverty in Rural India: A Review of Evidence. Economic and Political Weekly, 23(13), A36-A44.

\section{Theses/Working Papers}

Afshan, M., (2012), Structural Transformation and Economic Growth - A Comparative Study of J\&K State \& Other Northern States. (Doctoral dissertation). University Of Kashmir, Srinagar.

Athukorala, P., Sen, K., (2015), Industrialisation, Employment and Poverty. (Working Paper, Australian National University). Retrieved from https://crawford.anu.edu.au/acde/ publications/publish/papers/wp2015/wp_econ_2015_11.pdf

Aziz, J., (2010), Economic History of Modern Kashmir with Special Reference to Agriculture; 1947-1989. (Doctoral dissertation). University of Kashmir, Srinagar.

Bhagat, R., Das, K., (2008), Levels, Trends and Structure of Workforce in India: Census-based Study 1981-2001. (Paper, International Institute for Population Sciences, Mumbai). Retrieved from http://iipsindia.org/pdf/b01cBhagat per cent20sir's per cent20report.pdf

Davis, J., Bezemer, D., (2004), The Development of Rural Non-farm Economy in Developing Countries and Transition Economies: Key Emerging and Conceptual Issues. (Paper, Natural Resources Institute, University of Greenwich, London). Retrieved from http://projects.nri. org/rnfe/pub/papers/keyissues.pdf .

Jonasson, E., Helfand, S., (2008), Locational Determinants of Rural Non-agricultural Employment: Evidence from Brazil. (Paper, University of Californian, Riverside). Retrieved from http://economics.ucr.edu/papers/papers08/08-02.pdf .

Reardon, T., Berdegue, J., Barrett, C., \&Stamoulis, K., (2006), Household Income Diversification into Rural Nonfarm Activities. (Paper, Cornell University, New York). Retrieved from http:// barrett.dyson.cornell.edu/Papers/IFPRlbookchapter2006Final.pdf

Sen, P. ,(2007), India: What ever Happened to Industrialisation? (Paper, University of Pittsburgh). Retrieved from https://ipec.gspia.pitt.edu/Portals/7/Papers/Partha per cent20Sen.pdf.

Sharma, R., (2007), Agricultural Development and Crop Diversification in Jammu and Kashmir. (M. Phil Dissertation). Jawaharlal Nehru University, New Delhi.

Sharma, R., (2010), Diversification in Rural Livelihood Strategies: A Macro-Level Evidence from Jammu and Kashmir. (Working Paper, Centre for Development Studies, Thiruvananthapuram).

Retrieved from http://www.cds.edu/wp-ontent/uploads/2012/09/wp439.pdf . 


\section{Websites}

Directorate of Economics and Statistics, Department of Agriculture, Government of India. (n.d). Agricultural statistics at a glance. Retrieved from http://eands.dacnet.nic.in/PDF/ Agricultural-Statistics-At-Glance2014.pdf

India Science \& Technology for Rural India and Inclusive Growth, National Institute of Science Technology and Development Studies. (2008).Non-farm occupation in rural India. Retrieved from http://www.nistads.res.in/indiasnt2008/t6rural/t6rur2.htm

A.K. Mukhopadgyay et. al. (2008), Growth and structure of employment in India: Long-term and post-reform performance and the emerging challenge.Institute for Studies in Industrial Development. Retrieved from http://isidev.nic.in/pdf/ICSSR_TSP_PPS.pdf

Jammu and Kashmir ENVIS Centre, Department of Ecology Environment and Remote Sensing, Government of Jammu and Kashmir. (n.d). Average yield of principal crops. Retrieved from http://www.jkenvis.nic.in/agriculture_average_yield_principal_crops.html

Jammu and Kashmir ENVIS Centre, Department of Ecology Environment and Remote Sensing, Government of Jammu and Kashmir. (n.d). Net State Domestic Product. Retrieved from http://www.jkenvis.nic.in/administrative_economy_nsdp_sectoral_percentage.html

Jammu and Kashmir ENVIS Centre, Department of Ecology Environment and Remote Sensing, Government of Jammu and Kashmir. (n.d). Total area sown under different crops. Retrieved from http://www.jkenvis.nic.in/agriculture_area_sown.html

Ministry of Home Affairs, Census of India. (n.d). Census operations. Retrieved from http:// censusindia.gov.in/Data_Products/Library/Indian_perceptive_link/Census_Operation_link/ censusoperation.htm

Ministry of Home Affairs, Government of India. (n.d). Census highlights, Madhya Pradesh. Retrieved from http://censusmp.nic.in/censusmp/Data/PCA per cent20DATA/006 per cent20- per cent20Chapter per cent20- per cent204 per cent20- per cent20WPR per cent20. pdf

Ministry of Statistics and Programme Implementation, Government of India. (n.d). Major concepts and definitions. Retrieved from http://mospi.nic.in/Mospi_New/upload/nsso/ concepts_61R.pdf

Ministry of Statistics and Programme Implementation, Government of India. (2016). Statistical yearbook India 2016.Retrieved from http://mospi.nic.in/Mospi_New/upload/ SYB2016/CH-32-LABOUR-EMPLOYMENT/ch32.pdf

Directorate of Economics and Statistics, Government of Jammu and Kashmir (n.d.) J\&K in Indian Economy 2014-15, Retrieved from http://ecostatjk.nic.in/publications/publications. htm 


\section{Government Publications}

Planning Commission of India., (2003), State development report Jammu and Kashmir. Retrieved from http://planningcommission.nic.in/plans/stateplan/sdr_jandk/sdr_jkch4.pdf

Planning Commission of India. (2008). Eleventh five year plan-Inclusive growth. Retrieved from http://planningcommission.nic.in/plans/planrel/fiveyr/11th/11_v1/11th_vol1.pdf

\section{Conference/Seminars}

Choi, J., (2004), Policies and measures for promoting rural non-farm employment. In T. Onchan (Ed.), Non-Farm Employment Opportunities in Rural Areas in Asia.Report of the Asian Productivity Organisation seminar, Philippines.

Hirway, l., (1999), Estimating workforce using time use studies in India and its implications for employment policies. In International Seminar on Time Use Studies. Ahemadabad.

\section{Organisation}

United Nations Economic and Social Commission for Asia and the Pacific. (2012). Structural change, industrialization and poverty reduction: The case of India. Retrieved from http://www. unescap.org/sites/default/files/SSWA_Development_Paper_1206_Nov2012.pdf 